\title{
WYDAWNICTWA
}

\section{Wiesława Korzeniowska, Myśl pedagogiczna na przestrzeni wieków. Chro- nologiczny słownik biograficzny, Oficyna Wydawnicza „Impuls”, Kraków 2011, ss. 254}

DOI: 10.14746/BHW.2014.31.14

Nakładem Oficyny Wydawniczej „Impuls” w roku 2011 ukazała się praca Wiesławy Korzeniowskiej Myśl pedagogiczna na przestrzeni wieków. Chronologiczny słownik biograficzny.

W środowisku polskich historyków wychowania tego typu publikacje, słowniki biograficzne, są nader częste i popularne. Wystarczy wspomnieć chociażby kultową pracę Wincentego Okonia Wizerunki sławnych pedagogów polskich, Słownik pedagogów polskich pod redakcją Wandy Bobrowskiej - Nowak i Danuty Dryndy albo zbiorowe opracowanie Słownik biograficzny polskiej historii wychowania pod redakcją Andrzeja Meissnera i Władysławy Szulakiewicz ${ }^{1}$.

Niesłabnącą wciąż popularnością cieszy się także niezwykłe wydawnictwo, jakim jest Polski słownik biograficzny², epokowe dzieło Władysława Konopczyńskiego.

Przywołana w pierwszym wersie praca, jak sugeruje już sam jej tytuł, także jest zbiorem biogramów. Ale nieco innym...Odmienność ta została zasygnalizowana przez autorkę także w tytule. Autorzy biogramów zwykle wybierają alfabetyczny porządek swojej pracy, głównie z myślą o czytelniku, dla którego właśnie taki układ treści jest najbardziej logiczny i prosty w lekturze. Wiesława Korzeniowska zdecydowała inaczej i oparła swoją narrację biograficzną na chronologii. Czy było to posunięcie słuszne? Jakie cele przyświecały autorce w wyborze tak niecodziennego porządku w pracy o charakterze słownikowym? Czy jej plany były słuszne, a zamierzenia zostały osiągnięte?

Wiele wyjaśnień zostało zawartych we „Wstępie” książki, gdzie zdefiniowała Autorka swoje posłannictwo jako przypomnienie wzorów, postaw oraz wysiłków licznych

1 W. Okoń, Wizerunki sławnych pedagogów polskich, Wydawnictwo Akademickie „Żak”, Warszawa 2000; Stownik pedagogów polskich, pod red. W. Bobrowskiej-Nowak i D. Dryndy, Katowice 1998, Słownik biograficzny polskiej historii wychowania, pod red. Andrzeja Meissnera i Władysławy Szulakiewicz, Wydawnictwo Adam Marszałek, Toruń 2008.

2 Polski słownik biograficzny wydawany jest od 1935 r. 
przedstawicieli pedagogiki w przeszłości jako swego rodzaju energii moralnej ${ }^{3}$. Zadaniem prezentowanej publikacji było ponadto zaszczepienie kultu dla tradycji [...] oraz upowszechnianie szeroko rozumianej kultury pedagogicznej.

Praca oparta jest na przedstawieniu 660 biogramów postaci, które odegrały mniej lub bardziej ważką rolę w historii wychowania. Chronologia zaś została oparta na datach urodzenia tych postaci, stąd autorce łatwiej było podzielić treść na rozdziały, które odpowiadają podziałowi na epoki: starożytną, średniowieczną, renesansową, nowożytną (?), XIX i początków XX w. oraz najnowszą. Przed każdym z rozdziałów Wiesława Korzeniowska umieściła krótki wstęp dotyczący tendencji, występujących w poszczególnych okresach historycznych. Wybór sylwetek był podyktowany kryterium innowacyjności.

Chronologiczny słownik biograficzny został napisany przede wszystkim dla studentów pedagogiki, nauczycieli i pracowników szeroko pojętych instytucji edukacyjno-opiekuńczo-wychowawczych. Potencjalnymi odbiorcami mogą też być, według Autorki, sympatycy systemów filozoficznych oraz osoby zainteresowane psychologią.

Jak ocenić można zatem tak zaplanowane przedsięwzięcie?

Niestety negatywnie $\mathrm{i}$ to $\mathrm{z}$ wielu powodów.

Przede wszystkim z powodu naiwności autorki przy obiorze motywów do napisania książki. Trudno bowiem budować etos dyscypliny, kult dla tradycji i kulturę pedagogiczną w oparciu o dość ubogą literaturę przedmiotu (w przypisach królują głównie książki - podręczniki i prace nieco przestarzałe, głównie z lat 70. i początków lat 80. XX w.) oraz dość naiwne i powierzchowne (np. prawie zupełnie pomijając rolę kobiet) rozdziały wprowadzające do każdej z epok. Nie znalazło się w nich bowiem nic, czego nie znalazłabym w dość słabo ocenianych przeze mnie pracach studenckich.

Po drugie, z powodu owej problematycznej chronologii w porządku narracji. Ta nie pracuje dobrze w przypadku prac o charakterze encyklopedycznym. Poza tym w tekście znalazły się biogramy postaci, których daty życia są niepewne i nieokreślone, zatem siła kryterium chronologii słabnie.

Mam także zastrzeżenia dotyczące ich wyboru postaci. Na czym bowiem ma polegać ich innowacyjność, o której pisała autorka we „Wstępie”? Czy na pewno na przykład Oldze Drahonowskiej-Małkowskiej bliżej było do myśli pedagogicznej, czy może raczej do praktyki? Dlaczego w biogramach jest tyle błędów merytorycznych, bo np. Jan Hellwig, osobiście mój pierwszy przełożony, nie był do końca życia zwiazany z Katedra Pedagogiki Uniwersytetu Adama Mickiewicza w Poznaniu, ale z Wydziałem Studiów Edukacyjnych tejże uczelni ${ }^{5}$ ?

Plusem publikacji jest staranna szata graficzna, ładna, choć skromna okładka.

Autorka pomyliła się także częściowo, pisząc, że jej książka spodoba się sympatykom systemów filozoficznych oraz osobom zainteresowanym psychologią. Otóż nie, te osoby szukać będą innych prac, lepszych. $Z$ pewnością jednak prezentowana praca spodoba się

${ }^{3}$ W. Korzeniowska, Myśl pedagogiczna na przestrzeni wieków. Chronologiczny słownik biograficzny, Kraków 2011, ss. 9.

4 Ibidem.

5 Ibidem, s. 231. 
studentom, szczególnie zaś tym, którzy lubią przysłowiową „drogę na skróty”, bo ta książka jest najlepszym do tego instruktarzem.

Edyta Głowacka-Sobiech

\section{Adam Fijałkowski, Tradycja $i$ nowatorstwo w Orbis sensualizm pictus Jana Amosa Komeńskiego, Warszawa 2012, Wydawnictwo UW, ss. 410}

DOI: 10.14746/BHW.2014.31.15

W ostatnich latach w polskiej historiografii oryginalnych prac poświęconych edukacji i wychowaniu człowieka w XVII w. mamy niewiele. Tylko nieliczne, najczęściej uniwersyteckie ośrodki naukowe mogą poszczycić się takimi osiągnięciami. $Z$ wielką radością należy więc przyjąć kolejną nową publikację Adama Fijałkowskiego, dra hab. Uniwersytetu Warszawskiego, poświęconą pedagogice Jana Amosa Komeńskiego, który przez parę dziesiątków lat powiązany był z Polską, zwłaszcza z Lesznem, Gdańskiem i Elblągiem.

Książka jest niezwykle wnikliwym i dojrzałym studium monograficznym poświęconym jednej z najbardziej znanych publikacji Jana Amosa Komeńskiego, w której podjął bardzo interesującą próbę wykorzystania ilustracji (rysunku) jako narzędzia (sposobu) ułatwiającego poznanie treści (pojęciowego zasobu) użytego w zdaniu krótkiej czytanki łacińskiego słowa - w tłumaczeniu na język ojczysty ucznia. Cały ten zabieg metodyczny miał ułatwić uczniom poznanie i właściwe zrozumienie dziesiątków i setek łacińskich słówek, które stanowiły podstawę uczenia się. Za punkt wyjścia w poszukiwaniu owego „,nowatorstwa pedagogicznego” przyjął Autor pierwsze wydanie Orbis sensualizm pictus - owej niezbyt obszernej książeczki, którą Komeński wydał własnym sumptem w Norymberdze w 1658 r., a więc blisko 360 lat temu - wykorzystując najnowsze zdobycze techniki sztuki drukarskiej tamtych lat - w nadziei, że dzięki niej ułatwi uczniom naukę początkową łaciny, której z takim mozołem uczyły się narażeni nierzadko na karę cielesną za małe postępy w uczeniu się słówek. Faktem jest, że Orbis pictus spośród licznych jego dzieł stał się „najważniejszy” i uznaje się za „pierwowzór” podręcznika do nauki początkowej. Do końca XVIII w., doczekał się ponad 200 wznowień i był tłumaczony na 20 języków świata (zob. „Wstęp”, s. 9).

Autorowi tej publikacji, jak pisze we „Wstępie” - zależało nie na przypominaniu udziału Komeńskiego w działalności politycznej, jako biskupa i przywódcy duchowego braci czeskich w Polsce, bo ta znana jest z badań i prac Łukasza Kurdybachy, Bogdana Suchodolskiego, Tadeusza Bieńkowskiego i innych, ale zależało mu, w oparciu o nowe źródła na doprecyzowaniu znanych już faktów dotyczących genezy i treści Orbis pictus, a także na próbie znalezienia możliwie pełnej odpowiedzi na pytanie o przyczyny tak dużej popularności tego podręcznika i ustaleniu, $w$ jakim stopniu wpisywat się on we wcześniejsza tradycję szkolna, a w jakim byt rzeczywiście innowacyjny (s. 14-15).

Tak więc, badany przez Autora Orbis pictus traktowany jest jako element mikro-historii, która swe możliwości poznawcze i dydaktyczne czerpie z mikroskopowego oglądu, 